\title{
Babesia bovis: expression of adhesion molecules in bovine umbilical endothelial cells stimulated with plasma from infected cattle ${ }^{1}$
}

\begin{abstract}
Marlene I. Vargas², Joaquín H. Patarroyo ${ }^{2 *}$, Mayra Hernandez², Ana P. Peconick ${ }^{2}$, Adriana M. Patarroyo ${ }^{2}$, Gabriel A. Tafur ${ }^{2}$, Leandro S. Araújo ${ }^{2}$ and Fabrício Valente ${ }^{2}$

ABSTRACT.- Vargas M.I., Patarroyo J.H., Hernandez M., Peconick A.P., Patarroyo A.M., Tafur G.A., Araújo L.S. \& Valente F. 2014. Babesia bovis: expression of adhesion molecules in bovine umbilical endothelial cells stimulated with plasma from infected cattle. Pesquisa Veterinária Brasileira 34(10):937-941. Laboratório de Biologia e Controle de Hematozoários e Vetores, Departamento de Veterinária, Instituto de Biotecnologia Aplicada à Agropecuária, Universidade Federal de Viçosa, Campus Universitário, Viçosa, MG 36570900, Brazil. E- mail: jpatarro@ufv.br

Ten male, 12-month-old Jersey with intact spleens, serologically and parasitologically free from Babesia were housed individually in an arthropod-free isolation system from birth and throughout entire experiment. The animals were randomly divided into two groups. Five animals (group A) were intravenously inoculated with $6.6 \mathrm{X}^{1} 0^{7}$ red blood cells parasitized with pathogenic sample of Babesia bovis (passage 7 BboUFV-1), for the subsequent "ex vivo" determination of the expression of adhesion molecules. Five non-inoculated animals (group B) were used as the negative control. The expression of the adhesion molecules ICAM-1, VCAM, PECAM-1 E-selectin and thrombospondin (TSP) was measured in bovine umbilical vein endothelial cells (BUVECs). The endothelial cells stimulated with a pool of plasma from animals infected with the BboUFV-1 $7^{\text {th }}$ passage sample had a much more intense immunostaining of ICAM-1, VCAM, PECAM-1 E-selectin and TSP, compared to the cells which did not received the stimulus. The results suggest that proinflammatory cytokines released in the acute phase of babesiosis may be involved in the expression of adhesion molecules thereby implicating them in the pathophysiology of babesiosis caused by $B$. bovis.
\end{abstract}

INDEX TERMS: Babesia bovis, physiopathology, adhesion molecules, endothelial cells.

RESUMO.- [Babesia bovis: expressão de moléculas de adesão em células endoteliais de cordão umbilical de bovinos estimuladas com plasma de bovinos infectados.] Dez bezerros machos, da raça Jersey, com 1 ano de idade com baços "in situ", sorológica e parasitologicamente livres de Babesia, foram mantidos em baias individuais no isolamento a prova de artrópodes do Depto de Veterinária desde o nascimento e ao longo de toda a experimentação. Os animais foram divididos aleatoriamente em dois grupos. Cinco animais (grupo A) foram inoculados por via intravenosa com 6,6 $\times 10^{7}$

\footnotetext{
${ }^{1}$ Received on April 1, 2014.

Accepted for publication on July 9, 2014.

${ }^{2}$ Laboratório de Biologia e Controle de Hematozoários e Vetores, Departamento de Veterinária, Instituto de Biotecnologia Aplicada à Agropecuária (BIOAGRO), Universidade Federal de Viçosa, Campus Universitário, Viçosa, MG 36570-900, Brazil. *Corresponding author: jpatarro@ufv.br
}

hemácias parasitados com amostra patogênica de Babesia bovis (BboUFV - $17^{\mathrm{a}}$ passagem) , para a determinação subseqüente "ex vivo" da expressão de moléculas de adesão . Cinco animais não inoculados (Grupo B) foram utilizados como controlo negativo . A expressão de moléculas de adesão ICAM - 1, VCAM , PECAM - 1, E - selectina e trombospondina ( TSP) foi medida em células endoteliais da veia umbilical de bovinos (BUVECs). As células endoteliais estimuladas com um pool de plasma proveniente de animais infectados com BboUFV - 1 $7^{\mathrm{a}}$ passagem tinham uma imunocoloração muito mais intensa de ICAM - 1, VCAM , PECAM - 1 de E - selectina e de TSP , em comparação com as células que não receberam o estímulo . Os resultados sugerem que as citocinas pró-inflamatórias liberados na fase aguda da babesiose pode estar envolvida na expressão de moléculas de adesão , implicando , assim, elas na fisiopatologia da babesiose causada por B. bovis. 
TERMOS E INDEXAÇ̃̃O: Babesia bovis, fisiopatologia, moléculas de adesão, células endoteliais.

\section{INTRODUCTION}

Bovine babesiosis is one of the most important infections responsible for economic losses in cattle production around the world, with a greater importance in Australia, Latin America, and Africa. Eight species of Babesia that affect bovines was reported (Uilimber 2006). Nonetheless, In Latin America Babesia bovis and Babesia bigemina are species that occur, and Babesia bovis is considered the most pathogenic.

Babesiosis induced by B. bovis causes cerebral babesiosis and multiple organ failure. In the microcirculation level could occurs the adhesion of parasitized or non-parasitized erythrocytes on endothelium as prerequisite to trigger syndrome (Patarroyo et al. 1982; Caetano 2001). The similarities in the pathophysiology and clinical manifestations in babesiosis caused by B. bovis and malaria caused by Plasmodium falciparum were recognized by Clark \& Jacobson (1998). In both pathologies were founded cytoadherence of erythrocytes in the capillary beds as more characteristic lesion (Wright et al. 1989).

The cytoadherence occurs due to the action of parasites, or their metabolic products. They induce structural and/ or antigenic changes in erythrocytes membrane, creating binding sites for receptors expressed in endothelial cells (Gohil et al. 2010).

Proteins involved in cytoadhesion have been described in P. falciparum and in B. bovis; the erythrocyte membrane protein 1 (PfEMP1) and 3 (PfEMP3) from the former and, the variable erythrocyte surface antigen 1 (VESA-1), from the later, these proteins are believed to cause adhesion although their endothelial ligands are unknown (Chen et al. 2000; O`Connor \& Allred 2000).

Nonetheless, in P. falciparum infection was demonstrated several adhesion molecules, including ICAM-1, PECAM-1, thrombospondin (TSP), P-selectin, E-selectin and VCAM-1, expressed on the endothelium surface of capillary beds, playing an important role for P. falciparum cytoadherence (Berendt et al. 1989, Treugiter et al. 1997, Ho et al. 1998).

Even though the pathophysiology similarities in both infections, few studies have focused on the adhesion molecules occurring during babesiosis caused by B. bovis. A review by Cooke et al. (2005), only mentions TSP. In vitro adhesion experiments show that red blood cells infected by $B$. bovis adhere to surfaces treated with TSP and laminin (Parrodi et al. 1989)

Additionally, not all samples of $B$. bovis can cause cytoadherence or severe manifestations of the infection, inclusively when the populations have been cloned from the same virulent isolate (Nevils et al. 2000).

Despite that no suitable model for B. bovis study exists, bovine cerebral microvascular endothelial cells are able to promote in vitro adhesion of parasitized erythrocytes. Regardless the application of its experimental procedures represented a new approach for the research of babesiosis caused by $B$. bovis, although there receptors remain undefined (O`Connor et al. 1999).
The study and characterization of molecules expressed by the parasite and its ligands may bring innovative methods to prevent bovine babesiosis. For instance, the use of monoclonal antibodies against molecule or molecules expressed on the erythrocyte membrane with the purpose of blocking these proteins and preventing ligation with adhesion molecules.

The present work shows the expression, of the adhesion molecules PECAM-1, ICAM-1, E-selectin, TSP and VCAM, on bovine umbilical vein endothelial cells, stimulated with plasma from bovines infected with a virulent sample of $B$. bovis.

\section{MATERIALS AND METHODS}

Parasite. A strain of Babesia bovis, BbovUFV1 $7^{\text {th }}$ passage, virulent, isolated from bovine infected in Viçosa/MG, Brazil was used in this study. The sample was cryopreserved in liquid nitrogen. The passages of the strains were always made by needle inoculation in splenectomized calves (Bos taurus taurus) serologically and parasitologically free from Babesia.

Experimental animals and infection. All animals used in the experiment received treatment in accordance with the animal experimentation rules described in the International Guiding Principles for Biomedical Research Involving Animals. Ten male, 12-month-old Jersey with intact spleens, serologically and parasitologically free from Babesia were housed individually in an arthropod-free isolation system from birth and throughout entire experiment. The animals were fed fodder and pellet (20\% protein) and receiving water ad libitum. The animals were randomly divided into two groups. Five animals (group A) were intravenously inoculated with $6.6 \times 10^{7}$ red blood cells parasitized with the BbovUFV1 $7^{\text {th }}$ passage sample. Five non-inoculated animals (group B) were used as the negative control. The groups were clinically and parasitologically observed from one day before the inoculation to 18 days after the inoculation. Blood for obtain plasma was collected every 48 hours to lessen the stress of infected animals.

Isolation and maintenance of bovine umbilical vein endothelial cells (BUVECs). Bovine umbilical vein endothelial cells (BUVEC) were isolated from fresh veins using collagenase type II, according to the protocol previously described by Jaffe et al. (1973) with some modifications: cells were cultivated in complete DMEM plus $10 \%$ inactivated fetal bovine serum, $2 \mathrm{mM}$ glutamine, $1 \mathrm{mM}$ $\mathrm{CaCl}_{2}, 1 \mathrm{mM} \mathrm{MgCl}, 1 \%$ antibiotic/antimycotic, cultured in $75-\mathrm{cm}$ bottles and incubated at $37^{\circ} \mathrm{C}$ and $5 \% \mathrm{CO}_{2}$, with media changed every 48 hours.

The identity of the endothelial cells was determined morphologically, observing the polygonal appearance and confluent areas exhibiting the typical "cobblestone" appearance. To confirm the identity, after seven passages of culture, a monolayer was incubated for four hours, with $10 \mu \mathrm{g} / \mathrm{ml}$ of (Dil-Ac-LDL; Biomedical Technologies, Stoughton, Mass) and observed under immunofluorescence microscopy.

Expression of adhesion molecules. After the formation of the semi-confluent monolayer of BUVECs, the culture medium was replaced, and $200 \mu \mathrm{l}$ of a pool of plasma from animals in acute phase (14 days after the inoculation) with BbovUFV1 $7^{\text {th }}$ passage was added to the new medium. At that time inoculated animals showed clinical signs and parasitemia indicating that the cytokines and proinflammatory IL would be circulating in greater quantity, stimulating endotelial cells.

The cells were incubated for two hours. Endothelial cells with a pool of plasma from animals of group B were similarly incubated and used as a negative control. The identification of the adhesion molecules was carried out according to protocol previously descri- 
bed by Prudhommme et al. (1996), with some changes: PBS (pH 7.2, $2.9 \mathrm{mMNa}_{2} \mathrm{HPO}_{4} \times 7 \mathrm{H}_{2} \mathrm{O}, 154 \mathrm{mM}, \mathrm{NaCl}$,and $1 \mathrm{mM}, \mathrm{KH}_{2} \mathrm{PO}_{4}$ ) was used instead of PBS with 0,1\% BSA and IgG rabbit anti-mouse IgG or goat anti-rabbit IgG conjugated with peroxidase, were used instead of biotinylated anti-mouse IgG and diaminobenzidine (DAB).

After stimulation, the cells were washed with PBS pH 7.2, fixed with $4 \% \mathrm{v} / \mathrm{v}$ paraformaldehyde for 20 minutes and washed twice with PBS pH 7.2. Cells were then placed in 0,1 M PBS-glycine for 10 minutes and washed twice with $\mathrm{PBS} \mathrm{pH}$ 7.2. Endogenous peroxidase was blocked with a solution of $4 \% \mathrm{H}_{2} \mathrm{O}_{2}$ in $\mathrm{PBS} \mathrm{pH} 7.2$ for 20 minutes. Nonspecific binding was blocked using $10 \%$ horse serum in PBS for 30 minutes. Cells were then washed twice with PBS ( $\mathrm{pH} 7.5$ ). The cells were incubated over night at $4^{\circ} \mathrm{C}$ in a humidity chamber, with the monoclonal antibodies (Moabs) anti ICAM1, (CD54) clone 15.2; VCAM (CD106) clone B-K9; PECAM-1 (CD31) clone JC/70A and thrombospondin (TSP) clone A6.1 and the polyclonal monospecific anti-E-selectin (CD 62-E) all produced by Neo Markers ${ }^{\circledR}$ and diluted 1:80 in PBS (pH 7.2). The adhesion molecules were detected with rabbit anti-mouse IgG conjugated with horse radish peroxidase (Sigma ${ }^{\circledR}$ diluted at 1:200) and with goat anti-rabbit IgG conjugated with peroxidase (Sigma ${ }^{\circledR}$ diluted $1: 300$ ), both specific for the heavy and light chains. DAB was used as chromogen for the subsequent counter-staining with Harris Hematoxylin.

\section{RESULTS}

\section{Animal infection}

Ten days after inoculation were observed in one of the inoculated animals onset of some clinical signs of babesiosis as increased rectal temperature (more than $39^{\circ} \mathrm{C}$ ), reduced packet cell volume (PCV) (exceeding 30\%) occurred at same time of appearing of the parasite in circulating erythrocytes. In the rest of calves the clinical sings began on the 12th day post-inoculation. The maximum parasitaemia observed was $0.8 \%$ in day 14 post infection and nervous signs were observed in three calves on the same day.

\section{Endothelial cells}

After seven passages, the cultures were free from contaminating cells; the confluent monolayer exhibited the typical "cobblestone" appearance, and the uniformity to retain Dil-Ac-LDL. The fluorescence was present in the cytoplasm and cell membrane, but not in the nucleus. (Data not shown)

\section{Expression of adhesion molecules}

Figure 1 shows the results of the indirect immunoperoxidase staining using monoclonal antibodies against ICAM1 (Fig.1A), VCAM (Fig.1C), PECAM-1 (Fig.1E), TSP (Fig.1G), and polyclonal antibody against E-selectin (Fig.1I). All the stimulated BUVECs were positively immunostained, and the staining was evenly distributed on the cell surface. More intense immunostaining was found in the stimulated cells, compared with control cells which did not stained positive for VCAM and TSP (Fig.1D,F). As observed in Figure $1 \mathrm{I}$, the staining of E-selectin was more intense than that the other molecules.

\section{DISCUSSION}

The plasma used for stimulation was collected from animals in the acute stage of babesiosis and possibly contained high levels of proinflammatory cytokines. One of the

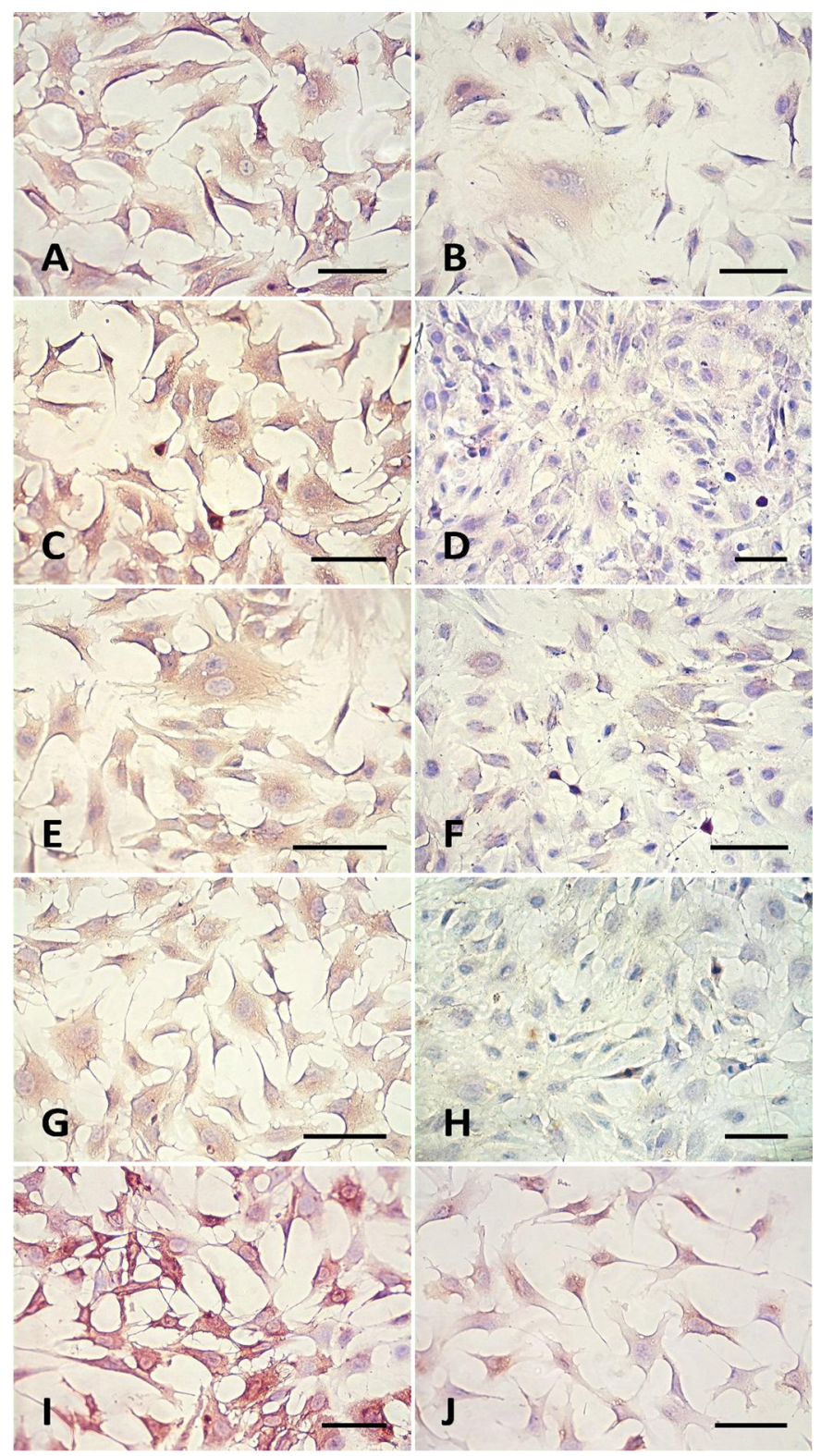

Fig.1. Expression of adhesion molecules in bovine umbilical endothelial cells (BUVECS) after stimulation with a pool of plasma from infected animals with Babesia bovis strain BboUFV1 $7^{\text {th }}$ passage. (A) ICAM, (B) Control of ICAM. (C) VCAM, (D) Control of VCAM. (E) PECAM, (F) Control of PECAM, (G) TSP, (H) Control of TSP. (I) E-Selectin, (J) Control of E-Selectin. Scale bar $100 \mu \mathrm{m}$.

roll of cytokines is stimulate expression of several adhesion molecules on the surface of endothelial cells. Previous research showed an increase in cytokines TNF- $\alpha$, IFN- $\gamma$ and IL12 in the plasma of animals inoculated with the BboUFV-1 $7^{\text {th }}$ passage sample, compared with control animals (De Freitas, 2001). These data agree with the works of Shoda et al. (2000) and East et al. (1997), who measured cytokines expressed by macrophages in animals infected with $B$. bovis.

Likewise, the proinflammatory cytokines such as TNF- $\alpha$ and IFN- $\gamma$ appear to be responsible for several biological activities on endothelial cells, as the stimulation of $\mathrm{FC} \gamma$ re- 
ceptors (Pan et al. 1998). By other hand protein exoantigens can be found in the plasma of animals in the acute stage of babesioses. These exoantigens are released either by the parasite or by rupture of red blood cells (Ristic 1988). $B$. bovis exoantigens are a heterogeneous group of proteins that could help to stimulate the endothelial cells.

Intense expression of ICAM-1, VCAM, PECAM-1, E-selectin and TSP was observed in Fig.1A,C,E,G,I when compared with the control treatment. Furthermore the in vitro studies performed by Shoda et al. (2000) showed that macrophages derived from monocytes activated by $B$. bovis expressing high levels of proinflammatory cytokines IL-1 $\beta$ IL12 and TNF- $\alpha$. These facts suggest that the cytokines must also be present in infected animals of experiment, thereby allowing its circulation in the plasma.

The adhesion molecules ICAM- 1 and VCAM were intensely expressed in BUVECs when the cells were stimulated with plasma, concurring with the results obtained by Bevilacqua (1993). They indicated that the expression of these molecules may be regulated by many types of cytokines, including TNF- $\alpha$ and other immunomodulators.

PECAM-1 was intensely expressed in the endothelial cells stimulated, whereas the control endothelial cells had little PECAM-1 expression. These observations agree with the results of Müller et al. (2002), which showed the occurrence of homogeneous PECAM-1 expression in stimulated cultures of human umbilical vein endothelial cells (HUVEC) and human pulmonary microvascular endothelial cells (HPMEC) in pulmonary vascular disease. Apparently, the E-selectin expression in BUVECs was much higher than the expression of the other adhesion molecules studied. This may occur because E-selectin is the first adhesion molecule to be induced after stimulation with TNF for 1 to 2 hours. The non-stimulated endothelial cells also expressed E-selectin, but at a lower intensity. Research carried out by Bischoff \& Brasel (1995), proved that the E-selectin mRNA might be up-regulated by TNF- $\alpha$ in confluent monolayers of bovine endothelial cells.

The intense thrombospondin expression on the surface of the stimulated cells is divergence with the findings of Loganadane et al. (1997), who studied the expression of this molecule stimulated with the components of the extracellular matrix in HUBEC cultures. However, it is important to consider that this work did not deal with the correlation between concentration of the molecule in the sub-endothelial matrix and the culture density. These aspects affected the secretion of thrombospondin by endothelial cells in vitro.

The duration of the stimulus by the plasma used in our experiments was enough for the expression of adhesion molecules, considering Raab et al. (2002) findings. They demonstrated that mixture of cytokines, such as TNF- $\alpha$, IL- 1 or IFN- $\gamma$ added to the incubation medium, can synergistically modulate the expression of adhesion molecules, such as VCAM-1, ICAM-1, PECAM-1 CD-34, E and P-selectin in HUVECs.

Despite that the role of adhesion molecules expressed during inflammation is well known, little is known about its function at vascular endothelium level on framework of $B$. bovis infection. For Plasmodium falciparum, it is well known that molecules such as ICAM-1, PECAM-1, E-selectin and VCAM- 1 act as receptors of ligands on the parasitized red blood cells (Cooke et al. 1994, Chen et al. 2000, Senezuk et al. 2001). These findings suggest that some of these molecules could act as receptors for the adhesion of red blood cells to the vascular endothelium in animals infected by $B$. bovis. From all of that raises a hypothesis: if the both apicomplexa are similar, will be the same molecules involve in the pathology of babesiosis as in malaria?

Based on Yipp et al. (2000), the CD36 is considered to be the main receptor for cytoadhesion in malaria. Nevertheless, Hutchings et al. (2007) suggested that CD36 does not play a role in bovine babesiosis.

The in vivo expression of adhesion molecules is not always the same as in vitro. So, the limitations of in vitro models must be considered, with greater relevance the absence of essential tissue micro-environment physiological factors.

The use of human monoclonal antibodies is based on the research of Van Kampen and Mallard (2001), who demonstrated that the monoclonal anti-human VCAM-1 antibody is cross reactive to VCAM- 1 expressed in bovine aortic endothelial cells (BAECs), which has expression kinetics similar to that of humans VCAM-1. The results of the present work clearly demonstrate that the human monoclonal antibodies recognize bovine molecules, such as ICAM-1, PECAM-1 and thrombospondin.

Unlike in malaria caused by P. falciparum, the identity of the receptors and/or adhesion molecules that mediate the adhesion in babesiosis caused by $B$. bovis is still not understood.

\section{CONCLUSION}

The plasma from animals in acute phase of babesiosis caused by Babesia bovis stimulates in vitro endothelial cells to produce adhesion molecules, which may be cause of red cells cytoadherence; these molecules possibly have an important role in the pathophysiology of infection. Perhaps these molecules, as in malaria caused by Plasmodium falciparum, have the same role in babesiosis.

Acknowledgements.- The authors thank FAPEMIG (Minas Gerais State Research Foundation, Brazil) for providing financial support for the project. We thank Marcio A. Dias for technical assistance in the laboratory and Aloizio Carlos da Silva for assistance with animals experiment

\section{REFERENCES}

Berendt A.R., Simmonds D.L., Tansey J., Newbold C.I. \& Marsh K. 1989. Intercellular adhesion molecule- 1 is an endothelial cell adhesion receptor for Plasmodium falciparum. Nature 341: 57-59.

Bevilacqua M. 1993. Endothelial-leukocyte adhesion molecules. Annu. Rev. Immunol. 11:767-804.

Bischoff J. \& Brasel C. 1995. Regulation of P-selectin by tumor necrosis factor- $\alpha$. Biomed. Biophys. Res. Commun. 210:174-180.

Caetano B.C. 2001. Estudos de citoaderência "in vitro" de eritrócitos de bovinos inoculados com Babesia bovis (Starcovici, 1893) em células endoteliais de aorta bovina. Dissertação de Mestrado em Medicina Veterinária, Universidade Federal de Viçosa, Viçosa, MG. 70p.

Chen Q., Heddini A., Barragan A., Fernadez V., Pearce S.F. \& Wahlgren M. 
2000. The semiconserved head structure of Plasmodium falciparum erythrocyte membrane protein 1 mediates binding to multiple independent host receptors. J. Exp. Med. 192:1-10.

Clark I.A. \& Jacobson L.S. 1998. Do babesiosis and malaria share a common disease process? Ann. Trop. Med. Parasitol. 92:483-488.

Cooke B.M., Berendt A.R., Craig A.G., Macgregor J., Newbold C.I. \& Nash G.B. 1994. Rolling and stationary cytoadhesion of red blood cells parasitized by Plasmodium falciparum: separate roles for ICAM-1, CD36 and thrombospondin. Brit. J. Haematol. 87:162-167.

Cooke B.M., Mohandas N., Cowman A.F. \& Coppel R.L. 2005. Cellular adhesive phenomena in apicomplexan parasites of red blood cells. Vet. Parasitol. 132:273-295.

De Freitas C.M. 2001. Avaliação da resposta imune de bovinos inoculados com amostras atenuada e virulenta de Babesia bovis (Starcovici, 1893). Dissertação de Mestrado em Medicina Veterinária, Universidade Federal de Viçosa, Viçosa, MG. 74p.

East I.J., Zakrzewski H., Gale K.R., Leatch G., Dimmock C.M., Thomas M.B. \& Waltisbuhl D.J. 1997. Vaccination against Babesia bovis: T cell from protected and unprotected animals show different cytokine profiles. Inter. J. Parasitol. 27:1537-1545.

Gohil S., Kats L.M., Sturm A. \& Cooke B.M. 2010. Recent insights into alteration of red blood cells by Babesia bovis: moovin forward. Trends Parasitol. 26:591-599.

Ho M., Schollaardt T., Niu X., Looareesuwan S., Patel K.D. \& Kubes P. 1998. Characterization of Plasmodium falciparum infected erythrocyte and Pselectin interaction under flow conditions. Blood 91:4803-4809.

Hutchings C.L., Li A., Fernandez K.M., Fletcher T., Jackson L.A., Molloy J.B., Jorgensen W.K., Lim Ch.T. \& Cooke B.M. 2007. New insights into the altered adhesive and mechanical properties of red blood cells parasitized by Babesia bovis. Mol. Microbiol. 65:1092-1105.

Jaffe E.A., Nachman R.L., Becker C.G. \& Minick C.R. 1973. Culture of human endothelial cells derived from umbilical veins. Identification by morphological and immunologic criteria. J. Clin. Invest. 52:2745-2756.

Loganadane L.D., Berge N., Legrand C. \& Fauvel-Lafave F. 1997. Endotelial cell proliferation regulated by citokines modulates trombospondim-1 secretion into the subendothelio. Cytokine 9:740-746.

Müller A., Hermanns M., Skrynski C., Nesslinger M., Müller K. \& Khkpatrick J. 2002. Expression of the endothelial markers PECAM-1, vWf, and CD34 in vivo and in vitro. Exp. Mol. Pathol. 72:221-229.

Nevils MA., Figueroa J.V., Turk J.R., Canto G.J., Le V., Ellersieck M.R. \& Carson C.A. 2000. Cloned lines of Babesia bovis differ in their ability to induce cerebral babesiosis in cattle. Parasitol. Res. 86:437-443.

O'Connor R.M., Long J.A. \& Allred D.R. 1999. Cytoadherence of Babesia bovis-infected erythrocytes to bovine brain capillary endothelial cells provides an in vitro model for sequestration. Infect. Immun. 67:3921-3928.
O' Connor R.M. \& Allred D.R. 2000. Selection of Babesia bovis infected erythrocytes for adhesion to endothelial cells coselects for altered variant erythrocyte surface antigen isoforms. J. Immunol. 164:2037-2045.

Pan L.F., Kreisle R.A. \& Shi Y.D. 1998. Detection of Fc $\gamma$ receptors on human endothelial cells stimulated with cytokines tumour necrosis factor-alpha (TNF- $\alpha$ ) and interferon-gamma (IFN- $\gamma$ ). Clin. Exp. Immunol. 112:533-538.

Parrodi F., Wright I.G., Bourne A.S. \& Dobson C. 1989. In vitro adherence of bovine erythrocytes infected with Babesia bovis to trombospondina an laminin. Int. J. Parasitol. 19:567-569.

Patarroyo J.H., Vargas M.I. \& Bicudo P. 1982. Description of lesions in cattle in a natural outbreak of Babesia bovis infection in Brazil. Vet. Parasitolol. 11:301-308.

Prudhomme J., Sherman I., Land K., Moses A., Stengleins S. \& Nelsons J. 1996. Studies of Plasmodium falciparum cytoadherence using inmortalized human brain capillary endothelial cell. Int. J. Parasitol. 26:647-655.

Raab M., Daxecker H., Markovic S., Karimi A., Griesmacher A. \& Mueller M. 2002. Variation of adhesion molecule expressing on human umbilical vein endothelial cells upon multiple cytokine application. Clin. Chem. Acta. 321:11-16.

Ristic M. 1988. Babesiosis of Domestic Animals and Man. CRC Press, Florida. 255 p.

Senezuk A., Reeder J., Kosmala M. \& Ho M. 2001. Plasmodium falciparum erytrocyte membrane protein 1 functions as a ligand for P-selectin. Blood 98:3132-3135.

Shoda L.K.M., Palmer G.H., Florin-Christensen J., Florin-Christensen M., Godson D.L. \& Wendy C.B. 2000. Babesia bovis-Stimulated macrophages express interleukin $1 \beta$, interleukin-12, tumor necrosis factor alpha and nitric oxide and inhibit parasite replication in vitro. Infect. Immun. 68:5139-5145.

Treugiter C.J., Heddini A., Fernandez V., Muller W.A. \& Wahlgren M. 1997. PECAM-1/CD31, an endothelial receptor for binding Plasmodium falciparum-infected erythrocytes. Nat. Med. 3:1405-1408.

Uilinber G. 2006. Babesia: a historical overview. Vet. Parasitol. 138:3 -10.

Van Kampen C. \& Mallard B. 2001. Regulation of bovine intercellular adhesion molecule 1 (ICAM-1) and vascular cell adhesion molecule 1 (VCAM1) on cultured aortic endothelial cells. Vet. Immunol. Immunopathol. 79:129-138.

Wright I.G., Goodger B.V., Buffington G.D., Clark I.A., Parrodi F. \& Waltisbuhl D.J. 1989. Immunopathophysiology of babesial infections. Trans. R. Soc. Trop. Med. Hyg. 83:11-13.

Yipp B.G., Anand S., Schollaardt T.D., Patel K.D., Looareesuwan S. \& Ho M. 2000. Synergism of multiple adhesion molecules in mediating cytoadherence of Plasmodium falciparum-infected erythrocytes to microvascular endothelial cells under flow. Blood 95:2292-2298 